\title{
The Pet Trade and Extermination
}

\author{
By Carlos F. Lehmann
}

In Colombia, in South America, the biggest drain on some wildlife species is the international pet trade. For every quetzal or cockof-the-rock that reaches its destination alive, fifty die, and whole populations are being exterminated, says Dr. Lehmann, who is Director General of the Valle State Museum of Natural History. The skin trade, urged on by the need for foreign exchange, is another serious drain. National Parks are the only hope in Colombia as elsewhere, but the importing countries, such as the USA and these of western Europe, could do much to reduce the trade in both pets and skins.

THE devastation that is taking place in Colombia results not only 1 from the killing of animals, but, what is much more serious, the rapid destruction of the forests and other habitats. This together with continuous hunting and the more recent use of pesticides and poisons, is rapidly destroying the wildlife. It is urgent to establish national parks, or nature reserves, in some of the few areas still suitable for the purpose; otherwise before long, nothing will be left large enough to deserve preservation as a wild area.

Colombia is known the world over for the wealth of its bird life, or at least for the number of bird species recorded in its territory. Today, unhappily at least 500 of the listed forms are no longer to be found. Vast areas, where not many years ago there were beautiful and luxuriant tropical forests, have been converted into pasture or arable land. Most damage, not only to the fauna and flora, but also to the water supply and soil, is taking place in the Andes, which in Colombia branch in three Cordilleras, of which the central and eastern ones are the most affected. Shifting cultivation on the very steep slopes results in the soil being washed away, so that in very few years the forests become waste land and deserts or bare rocks, and the abundant wildlife disappears, or at best is replaced by a few new species of open country. Not even important watersheds escape destruction, and cities large and small are suffering from drought and a shortage of hydroelectric power, while the valleys lack the water necessary for cultivation.

Continuous hunting with no bag limits or close seasons, or regulations about killing females, is another problem. A third very serious problem is the commercialisation of wildlife, of which there are two aspects: the trade in live animals-the pet trade-and the trade in skins.

Every year thousands of live animals are exported from Colombia, and for every specimen that reaches its destination alive, many more die on the way through lack of care and improper food. This is true of the Colombian quetzal, cock-of-the-rock, many tanagers, and 


\section{Table 1: Species Exported from Leticia, Amazonas State}

Details supplied by señor Alberto Lemos B., Inspector of Hunting and Fishing, Ministry of Agriculture in 1966

\section{BABILLAS CAIMANS}

CAIMAN NEGRO (Yacare ( $\mathrm{N}$ eg ro ). Melanosuchus niger. Black caiman

CAIMAN BLANCO O

BABILLA. Caiman sclerops. Spectacled caiman

\section{PIELES DE LOBON O PERRO DE AGUA. Pteronura brasilensis Giant otter}

OTTERS Lutra sp.

\section{ZAINOS Y GUANGANAS Peccaries}

MICOS Monkeys

BOCABLANCA (Mariquina)

Marmosets

(Barrigudo) Lagothrix 1. Woolly monkey

\section{PECES ORNAMENTALES}

Fish

PIRARUCU (Arapaima gigas)
104,000 August to October; $85 \%$ less than $0.8 \mathrm{mts}$. of which $50 \%$ were 1000 than $0.6 \mathrm{mts}$. The other $15 \%$ not more than $2 \mathrm{mts}$.

8 skins monthly from June to December. Previously 1,000 to 2,000 monthly.

Small specimens $(60 \mathrm{cmts}$. to 1.01 mts.) fetch better prices than bis ones.

4 in three months. In provious years up to 200 monthly.

4 in one month. Previously 300 or more per month.

5,000 to 10,000 every three months by boat to Hamburg.

Saimiri caquetensis, squirrel monkeys, previously 20 to 50 a month, now 2,000 to 5,000 monthly.*

Proviously 5 to 15 weekly. Now 2,000 monthly.

Previously 400 to 500 monthly, now 2 or 3.

$1,700,000$ in 1965. According to invertigations 7 to $8,000,000$ fish must havo been captured.

In the last three months 35 kilos. Previously 800 to 900 kilos fortnightly.

*The large numbers of squirrel monkeys are due to the good prices paid by American Laboratories. 
Table 2: Skins and Live Specimens Exported in 1958 from the Port of Barranquilla only

\begin{tabular}{|c|c|c|c|}
\hline & & Skins & Live anir \\
\hline Venados & Deer & 614 & 48 \\
\hline Tigrillos & Ocelots & 6,186 & 1,243 \\
\hline Nutrias & Otters & 417 & 19 \\
\hline Ponches & Capibaras & 10,794 & 238 \\
\hline Pumas & Mountain lion & 124 & 71 \\
\hline Jaguares (tigres) & Jaguars & & \\
\hline Babillas & Small caimans & 104,786 & 4,318 \\
\hline Iguanas & & 92,701 & \\
\hline Caimanes & Large caimans & 645 & \\
\hline Monos (varias especies) & Monkeys & & 10,937 \\
\hline & & 216,429 & 16,896 \\
\hline EXPORT TOTALS & & & \\
\hline Reptile skins & & 198,422 & \\
\hline Mammal skins ...... & .......... & 18,007 & 216,429 \\
\hline Live mammals & & 12,564 & \\
\hline Live reptiles & . & 4,332 & 16,896 \\
\hline
\end{tabular}

Extract from the review "Caza Tiro y Pesca," No. 44, Barranquilla. April 1959

flesh-eating species. Thousands of tanagers die in the collectors' cages before they are shipped. With quetzals and cock-of-the-rock I believe that no fewer than 50 die for every one that survives. New capture methods make it increasingly easy to catch the birds, with the result that whole populations are being exterminated on some rivers; in one year a single dealer exported 300,000 . Parrots are shipped monthly to Mexico by the thousands and then smuggled into the United States. Not even reptiles or fish escape; hundreds of thousands are exported alive-lizards, caimans, turtles, and all kinds of fish. Turtle eggs are collected in very large numbers, mainly in the Magdalena, Meta, and Caqueta rivers, endangering the turtles' survival. The accompanying table gives the figures compiled by official inspectors in Cali and Leticia, and denounced by a sporting magazine of Barranquilla. In fact, the figures for Cali and Barranquilla are underestimates; many specimens leave the country unchecked. The figures for Cali and Barranquilla refer only to live specimens, while those for Leticia include 


\section{Table 3 : Species Exported to USA in 1965}

\section{Information supplied by the Hunting and Fishing Section of Valle State Dept. of Agriculture}

\section{Birds}

Primaveras

Cerrajas

Asomas

Azulejos

Cardenales

Pollo de monte

Garza roja (Ibis rojo). Scarlet ibis Garza corocora (Ibis rojo)

Yataro

Mirlas

Toche llanero

Pavas reales

Gallo de sierra

Tintin

Tirana

Tucanes

Chicaos

Yataro real
Toucans

Mocking birds

Carassow

Cock of the rock

Striped cuckoo

Sun bittern

Toucans

Oriole

Toucan
Compsocoma flavinucha 142

Cyanocorax yncas 94

Ramphocelus flammigerus 15

Thraupis virens 31

Ramphocelus dimidiatus 5

Cyanocorax violaceus 29

Eudocimus ruber 20

E. ruber 21

Ramphastos sp. 2

Mimus gilbus $\quad 18$

Gymnomystax mexicanus 1

Penelope sp.

Rupicola peruviana 39

Tapera naevia

Euripyga helias

Ramphastidae

Icterus mesomelas

Ramphastos tucanus

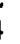

(5

5

9

20

1

8

\section{Mammals}

Mico choyo

Churucos

Perros de monte Mico maicero Tigrillo
Humboldt's woolly monkey Woolly monkey Kinkajou Brown capuchin Ocolot
Lagothrix lagothricha $\quad 8$ L.l lugens 6 Potos flavus 11 Cebus apella 8 Zibethailurus (Leopardus) pardalis

skins. Something must be done to control, if not to stop completely, this international pet trade.

In addition many game animals are slaughtered for their skinspeccary, deer, jaguar, ocelot, Amazonian otter (Pteronura); I have the records of a man who exported 480,000 skins a year. Other animals, such as the capybara, are killed by the thousand for their meat. The slaughtering of the capybara is one of the worst cases. The meat of this fishy-tasting animal is sold as fish, sometimes under the name 
of salmon. Venezuelan traders asked for permission to slaughter 300,000 capybara a year in Colombia. On my advice, as adviser to the Ministry, the Minister of Agriculture refused. The Venezuelans than brought a little pressure on another Minister, and he got them a permit for 50,000 a year; a little more pressure and they received another quota for 20,000 . But there is no control. The animals are herded into corrals and clubbed to death for their meat; the valuable skin is removed and thrown away. And that is not a wise way to use wildlife.

This skin trade is more difficult to stop than the trade in live animals, because some official agencies sponsor it in order to obtain foreign exchange. Importing countries, such as the USA, England, Holland, Belgium and Germany, could help a lot to reduce the live trade, or perhaps even stop it altogether, if they would reduce or prohibit imports of so-called "pets," and give licences only to wellestablished zoos.

Conservationists in Colombia are now striving for the establishment of national parks, and perhaps some nature reserves, but we need help to convince the government and persuade it to take action. Three reserves have recently been established in the north by CVM, a government agency for the development of the Magdalena and Sinu river valleys; the Sierra de la Macarena, an area of 11,000 square kilometres, has been made a nature reserve, and a small national park, the Cueva de los Guacharos, has been declared to protect the oil birds. Both need organisation and supervision. Two more areas have been selected by the Departments of Valle and Cauca: the Farallones de Cali, the highest mountain in the western Andes, in Valle; and Purace, in Cauca, in the Central Andes. Unfortunately, neither has yet been approved by the central government, and the destruction of flora and fauna continues. They should be saved before the destruction is such that they are no longer suitable for national parks.

Dr. Lehmann concluded by showing a film of the condor at Juanambu, in southern Colombia, where the deep canyons form a natural habitat for the birds and a few pairs still survive. The owner has agreed to give the bluffs that form the condor's home to the Colombia Society for the Conservation of Nature, and permit bird watchers and students to use his ranch-house. The Society is appealing for $\$ 10,000$ to provide proper access and facilities. 


\section{Conference Resolutions}

$A^{T}$ the final session of the San Diego Conference four resolutions were passed unanimously:

"The International Union for Conservation of Nature and Natural Resources be requested to implement, through its Survival Service Commission, the proposal to set up a translocation unit or group to collect and codify information in collaboration with FAO, coordinate future schemes for animal capture, transport, and wild release, especially of endangered species, and further, that IUCN should organise a symposium on immobilisation and other capture techniques."

"The San Diego Conference on Conservation recognises the urgent need for underwater parks and for the full protection in already established parks and preservation of aquatic, as well as terrestrial life, both freshwater and marine. The conference urges that due thought be given, and due action taken to implement this need."

"Noting that the present large-scale capture of wild primates is a serious drain on wild populations, and that the largest importation is by the United States for federally financed research and pharmaceutical production, the conference meting at San Digo in Octobr, 1966, therefore requests the competent federal authorities to consider the following points:

1. Closer evaluation of research grants in terms of the number of primates, and the merits of the individual request.

2. Requiring that primate procurement be so managed as to reduce the present large rate in mortality.

3. Giving support to all aspects of research concerning the captive breeding of primates for research purposes."

"That all participants in the conference express their warmest thanks to the San Diego Zoological Society for its foresighted sponsorship of the conference, and for all the hard work that its officials and those of Zoo-50 have put into the organisation of a unique occasion." 